\title{
Oxidative Stress and Beta Amyloid in Alzheimer's Disease. Which Comes First: The Chicken or the Egg?
}

\author{
Elena Tamagno ${ }^{1,2, *}$, Michela Guglielmotto ${ }^{1,2}$, Valeria Vasciaveo ${ }^{1,2}$ and Massimo Tabaton ${ }^{3}$ \\ 1 Department of Neuroscience, University of Torino, Via Cherasco 15, 10126 Torino, Italy; \\ michela.guglielmotto@unito.it (M.G.); valeria.vasciaveo@edu.unito.it (V.V.) \\ 2 Neuroscience Institute of Cavalieri Ottolenghi Foundation (NICO), University of Torino, Regione Gonzole 10, \\ Orbassano, 10043 Torino, Italy \\ 3 Unit of Geriatric Medicine, Department of Internal Medicine and Medical Specialties (DIMI), \\ University of Genova, Viale Benedetto XV 6, 16132 Genova, Italy; mtabaton@neurologia.unige.it \\ * Correspondence: elena.tamagno@unito.it; Tel.: +39-0116707764
}

check for updates

Citation: Tamagno, E.; Guglielmotto, M.; Vasciaveo, V.; Tabaton, M. Oxidative Stress and Beta Amyloid in Alzheimer's Disease. Which Comes First: The Chicken or the Egg? Antioxidants 2021, 10, 1479. https:// doi.org/10.3390/antiox10091479

Academic Editors: Stefania Pizzimenti, Giuliana Muzio and Giuseppina Barrera

Received: 21 August 2021 Accepted: 15 September 2021 Published: 16 September 2021

Publisher's Note: MDPI stays neutral with regard to jurisdictional claims in published maps and institutional affiliations.

Copyright: (c) 2021 by the authors. Licensee MDPI, Basel, Switzerland. This article is an open access article distributed under the terms and conditions of the Creative Commons Attribution (CC BY) license (https:/ / creativecommons.org/licenses/by/ $4.0 /)$.

\begin{abstract}
The pathogenesis of Alzheimer's disease involves $\beta$ amyloid (A $\beta$ ) accumulation known to induce synaptic dysfunction and neurodegeneration. The brain's vulnerability to oxidative stress (OS) is considered a crucial detrimental factor in Alzheimer's disease. OS and A $\beta$ are linked to each other because $A \beta$ induces OS, and OS increases the $A \beta$ deposition. Thus, the answer to the question "which comes first: the chicken or the egg?" remains extremely difficult. In any case, the evidence for the primary occurrence of oxidative stress in AD is attractive. Thus, evidence indicates that a long period of gradual oxidative damage accumulation precedes and results in the appearance of clinical and pathological AD symptoms, including A $\beta$ deposition, neurofibrillary tangle formation, metabolic dysfunction, and cognitive decline. Moreover, oxidative stress plays a crucial role in the pathogenesis of many risk factors for AD. Alzheimer's disease begins many years before its symptoms, and antioxidant treatment can be an important therapeutic target for attacking the disease.
\end{abstract}

Keywords: oxidative stress; $\beta$ amyloid; Alzheimer's disease

\section{Introduction}

Alzheimer's disease (AD) is considered the leading cause of dementia and is becoming one of the most expensive and deadly diseases of our time [1]. Thus, it is estimated that 50 million people worldwide endure dementia, and this number is set to rise to 152 million in 2050 [2,3]. Moreover, Alzheimer's patients need specialized and expensive care, the annual cost of treatment worldwide is around a trillion US dollars, and it is predicted that this cost will significantly increase by 2030 [4].

The pathophysiology of the disease is complex and multifactorial and certainly not entirely known [3]. There are two markers of the disease. One is $\beta$ amyloid (A $\beta)$, which accumulates abnormally in AD brain tissues and forms extracellular plaques known to induce synaptic alterations and neurodegeneration [5,6]. The other is Tau protein, which forms intracellular neurofibrillary tangles that are also responsible for neurodegeneration $[7,8]$.

AD is traditionally divided into two forms: early and late onset forms. The early onset form is closely associated with mutations on three genes: the genes that encode for the amyloid precursor (APP) and for presenilin 1 and presenilin 2, which represent the catalytic core of $\gamma$-secretase, a key enzyme for the production of $A \beta$ [9]. The late onset form is caused by complex interactions between genetic and environmental factors $[10,11]$. APOE is the gene that was first associated with the development of the late form [12] compared to other predisposing genes that have been described. These include genes involved in neuroinflammation (such as TREM2, TYROBP, and CD33) [13-15], memory (CR1, PICALM, and BIN1) [16-18], and lipid metabolism (ABCA7 and CLU) $[19,20]$.

Thus, although there are numerous factors associated with the development of the disease, $A \beta$ represents one that is the most closely related to its pathogenesis. $A \beta$ is 
composed of polypeptides of various lengths, and most of those found in the plaques are 40 and 42 amino acids long [6]. A $\beta 40$ is the most abundant form and accounts for $90 \%$ of the amyloid present in the plaques; however, the longer form (A $\beta$ 42) is predominant in the initial phases and aggregates faster than $A \beta 40$ [21]. A $\beta$ is produced from the amyloid precursor protein (APP). APP is an integral membrane protein with a large, extracellular $\mathrm{N}$-terminus and a shorter, cytoplasmic C-terminus [22,23]. The amyloidogenic processing of APP involves two sequential cleavages operated by the $\beta$-secretases and $\gamma$-secretases. The $\beta$-secretase (BACE1) cleaves APP, generating an extracellular soluble fragment called s $\beta$ APP and an intracellular C-terminal end termed C99 [24]. C99 is further cleaved, within the membrane, by the $\gamma$-secretase [25]. The $\gamma$-cleavage produces $A \beta$ fragments of different lengths, and these are predominantly $\mathrm{A} \beta 40$ and $\mathrm{A} \beta 42$ [25].

In the last 30 years, many authors supported the hypothesis of the "amyloid cascade" that considers $A \beta$ to possess a crucial role in the pathogenesis of the disease [26-30]. According to this theory, the accumulation and deposition of $A \beta$ is responsible for Tau aggregation and, therefore, for the cognitive and mnemonic decline observed in AD patients [31].

However, neither the rate of dementia nor the extent of neurological damage is correlated with the A $\beta$ aggregates [32]. Studies on transgenic mice carrying mutations in the gene for APP demonstrated the existence of soluble $A \beta$ (sA $\beta$ ) oligomers long before the deposition of $\beta$-amyloid, further supporting the hypothesis that, in particular conditions such as over-production, soluble $A \beta$ aggregates exist in the human brain even in the absence of plaques. The term soluble $A \beta$ is a working definition, which combines all forms of $A \beta$ derived from physiological brain extracts that remain in aqueous solution after highspeed centrifugation [33]. Soluble oligomers released by cells have been shown to cause neuronal dysfunction in vivo as well as synaptic loss and cognitive impairment [34-40].

Studies on Down Syndrome (DS) demonstrate that the presence of the APP gene in triplicate is most likely the cause of the early onset of signs of dementia in people with DS, see review [34]. Moreover, the accumulation of $A \beta$ is thought to play a fundamental role in triggering synaptic dysfunction in neurons and results in their eventual loss. Experimentally, soluble A $\beta$ oligomers have been found to selectively block hippocampal long-term potentiation (LTP), widely believed to underlie learning and memory $[35,36]$. Importantly, active and passive $A \beta$ immunotherapies have been shown to protect against the neuropathological and cognitive deficits observed in APP transgenic models of AD and in $\mathrm{AD}$ patients $[37,38]$.

Furthermore, the existence of a relationship between the molecular model of sA $\beta$ and the phenotype of the disease was suspected, and this connection reflected the type and degree of neurotoxicity of $A \beta$. The species of $s A \beta$ associated with physiological aging of the brain were compared with those present in sporadic cases of Alzheimer's disease, and it was found that the species of $\mathrm{sA} \beta$ in the two different conditions are different [39]. However, it must be emphasized that a recent paper has not found differences in homomeric, heteromeric and soluble $\mathrm{A} \beta$ between normal and Ad brains [40].

It has also been observed by Tagliavini's group that the assembly of mixtures of $A \beta$ peptides into different $A \beta$ seeds results in the formation of different subtypes of amyloid with distinctive physicochemical and biological properties resulting in the generation of distinct AD molecular subgroups [41]. Selkoe's group suggested that preventing soluble $\mathrm{A} \beta$ oligomer formation and targeting their $\mathrm{N}$-terminal residues with antibodies could be an attractive combined therapeutic approach [42].

Thus, there is a balance between $A \beta$ synthesis and degradation through self-regulatory pathways [43]. However, the destruction of this equilibrium results in the overproduction of $A \beta$ in brain tissue [6]. One of the main mechanisms that break this balance is oxidative stress (OS) and neuroinflammation [44]. OS is caused by a derangement between the production of reactive oxygen species (ROS) and the antioxidant defences of an organism.

OS and $A \beta$ are linked to each other because $A \beta$ induces OS in vivo and in vitro [44-46], and $O S$ increases the production of $A \beta[47-50]$. 


\section{A $\beta$ vs. Oxidative stress}

There are numerous mechanisms described in the literature by which beta amyloid $(\mathrm{A} \beta)$ mediates oxidative damage (Figure 1).

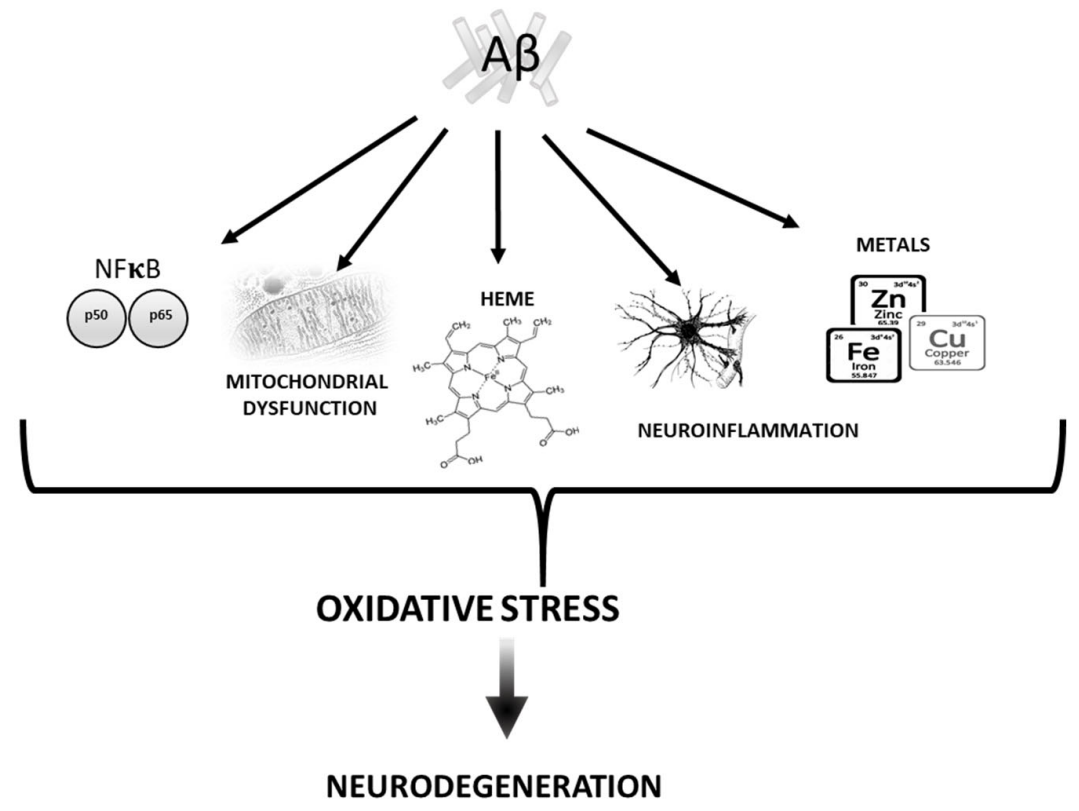

Figure 1. Diagram sketching mechanisms by which $A \beta$ induces oxidative stress.

\subsection{Mitochondria}

$A \beta$ interferes with the normal mitochondrial activity, causing dysfunction that results in oxidative stress [51]. Thus, neurons are cells that require high energy levels to perform numerous functions, such as the generation of action potentials, nerve transmission, and axonal transport [52].

The alteration of oxidative phosphorylation (OXPHOS) involves a reduction in the efficiency to transfer electrons, which in turn results in an increase in ROS production predominantly at level of complex I and complex III. These ROSs generated at the chain level unfold their damaging action mainly on mitochondrial macromolecules [53]. The peptide $\mathrm{A} \beta$ not only promotes the generation of ROS at the level of the mitochondria, but inhibits, at the same time, ROS removal. In fact, it has been shown that $A \beta$ is able to inhibit mitochondrial superoxide dismutase (MnSOD), the enzyme most involved in the detoxification of the anion superoxide and protection from peroxidative damage [54,55]. $\mathrm{A} \beta$ is also capable of binding and inhibiting mitochondrial alcohol dehydrogenase known as $\mathrm{ABAD}$ (A $\beta$ binding alcoholdehydrogenase). ABAD has a protective role, being responsible for the detoxification from aldehydes such as 4-hydroxinonenal. The interaction between the $\mathrm{A} \beta$ peptide and $\mathrm{ABAD}$ compromises the detoxification process for which the enzyme is responsible for, causing lipid peroxidation, ROS generation, and mitochondrial dysfunction [56].

Furthermore, from the direct impact of $A \beta$ on mitochondria, some authors also demonstrated that mitochondrial DNA is altered in elderly and AD patients [57]. Various factors can influence mitochondrial activity, contributing to AD progression. [58]. In brain tissue of AD cases, there is a downregulation of genes in mitochondrial complex I of the OXPHOS [59], and OS is implicated in mtDNA damage [60].

\subsection{Transition Metals}

Another mechanism found dysregulated in AD is the homeostasis of metals such as iron $(\mathrm{Fe})$, copper $(\mathrm{Cu})$, and zinc $(\mathrm{Zn})$. The blood-brain barrier tightly regulates the concentration of these metals, but their levels significantly increased in AD patients $[61,62]$. Studies have shown that $A \beta$ plaques contain traces of these metals [63], and $A \beta$ can 
reduce $\mathrm{Fe}$ (III) or $\mathrm{Cu}$ (II) to induce hydrogen peroxide $\left(\mathrm{H}_{2} \mathrm{O}_{2}\right)$ production, contributing to $\mathrm{OS}$ in $\mathrm{AD}$ [64]. Moreover, some studies suggested that these metals can increase A $\beta$ polymerization; thus, neuroblastoma cells treated with $\mathrm{Fe}^{3+}$ caused an increase in BACE1 activity that, in turn, promotes $A \beta$ production [65]. Moreover, zinc is also abundant in amyloid plaques, suggesting its role in $\mathrm{AD}$. Zinc interacts with $\mathrm{A} \beta$ protein, and this interaction can be prevented by chelators $[66,67]$. ZnA $\beta$ oligomers mediate stronger toxicity than amyloid-beta derived diffusible ligands (ADDLs) by cell viability assays [68]. The ex vivo study showed that $\mathrm{ZnA} \beta$ oligomers inhibited hippocampal LTP in a transgenic mouse model also through the production of ROS [69].

\subsection{Heme}

Another important iron containing molecule that has been implicated in the pathogenesis of $\mathrm{AD}$ is heme. Heme is an essential molecule in various physiological and pathological mechanisms [70]. It has been suggested that $\mathrm{AD}$ patients had lower hemoglobin levels and smaller cell volume with respect to normal aging controls [71]. Complexes II, III, and IV of the electron transport chain require heme to assembly cytochromes needed to function [72]. Perturbation in heme metabolism can cause oxidative stress and cell death [73]. Sankar and collaborators found that heme can mitigate the $A \beta 42$-mediated neuroinflammation activated by astrocytes [74]. Heme can also bind to $A \beta$, and this complex is known to have peroxidase activity able to oxidize serotonin and DOPA and providing an intriguing link between heme and oxidative stress in AD [75]. Thus, heme deficiency is followed by formation of APP dimers and loss of complex IV of the electron transport chain, and this event causes OS [76]. This finding suggested that iron accumulation observed in AD could be strictly linked to heme deficiency [76].

\subsection{Neuroinflammation}

Another crucial mechanism through which the presence of $A \beta$ induced oxidative stress is neuroinflammation [77]. Neuroinflammation is considered as an immunological response characterized by the activation of glial cells and the production of inflammatory mediators [78]. Numerous studies revealed a strong correlation between neuroinflammation and AD pathology [79-81]; thus, inflammatory cytokines have been reported to increase in the progression of mild cognitive impairment to overt AD [82]. A microarray study of Cribbs and collaborators performed on young, aged, and AD cases demonstrated an upregulation of the innate immune response in aging brains and a slight increase in related genes [83], suggesting that inflammation has a role in the preclinical stages of $\mathrm{AD}$. In this context, microglia play a leading role in neuroinflammation [78]. A $\beta$ can bind different microglial receptors, resulting in the production not only of inflammatory cytokines and chemokines [83] but also of a large amount of oxygen free radicals $\left({ }^{\bullet} \mathrm{OH}\right.$ and $\mathrm{O}_{2}{ }^{\bullet}$ ) [84], nitric oxide $\left({ }^{\bullet} \mathrm{NO}\right)$ [85], and tumour necrosis factor (TNF) $\alpha$ [86]. The NLR family pyrin domain containing 3 (NLRP3) inflammasome is a recently found cytoplasmic protein complex involved in neuroinflammation and innate immune response [87]. Recent studies demonstrated that A $\beta$ induce NLRP3 activation in microglia and astrocytes. This event results in the production of caspase 1 and induces the release of cytokines such as IL1 $\beta$ and IL-18, resulting in irreversible damage. On the other hand, the inhibition of NLRP3 inflammasome inhibits $\mathrm{A} \beta$ deposition and had a neuroprotective effect in a transgenic $\mathrm{AD}$ mouse model [88-91]. Thus, all these findings suggest that $A \beta$ is a crucial factor in $A D$ associated inflammation and oxidative stress.

\subsection{NF-kB Pathway}

The NF-kB family also has an important role in modulating oxidative stress. Thus, evidence from in vitro studies showed increased oxidative stress-mediated by NF-kB in response to neurons exposed to $A \beta$; this increased oxidative stress resulted in the accumulation of lipid peroxides and neurodegeneration [92]. Moreover, many studies confirm that $\mathrm{A} \beta$ peptides stimulate NF-kB gene expression and its nuclear translocation [93-95]. 


\section{Oxidative Stress vs. A $\beta$}

As mentioned in the Introduction Section, neurons, unlike other cells, use a large amount of oxygen; therefore, their mitochondria produce large amounts of ATP. This aspect is closely linked to the fact that they are production sites of reactive oxygen species and extremely sensitive to the resulting damage [44].

OS increase is considered to be an early event in AD pathology [96,97], as it contributes to membrane damage, cytoskeleton alterations, and cell death [98].

Thus, the identification of a large number of oxidatively modified proteins in common $\mathrm{AD}$ and $\mathrm{AD}$ animal models $[99,100]$ suggests that OS plays an important role in AD pathogenesis. Moreover, extensive oxidative damage observed in mild cognitive impairment (MCI) [101] suggests that OS may be an early event in the progression from normal aging to $\mathrm{AD}$ pathology. Based on these notions, it seems likely that increased production of ROS may act as important mediators of synaptic loss and eventually promote senile plaques formation [102] (Figure 2).

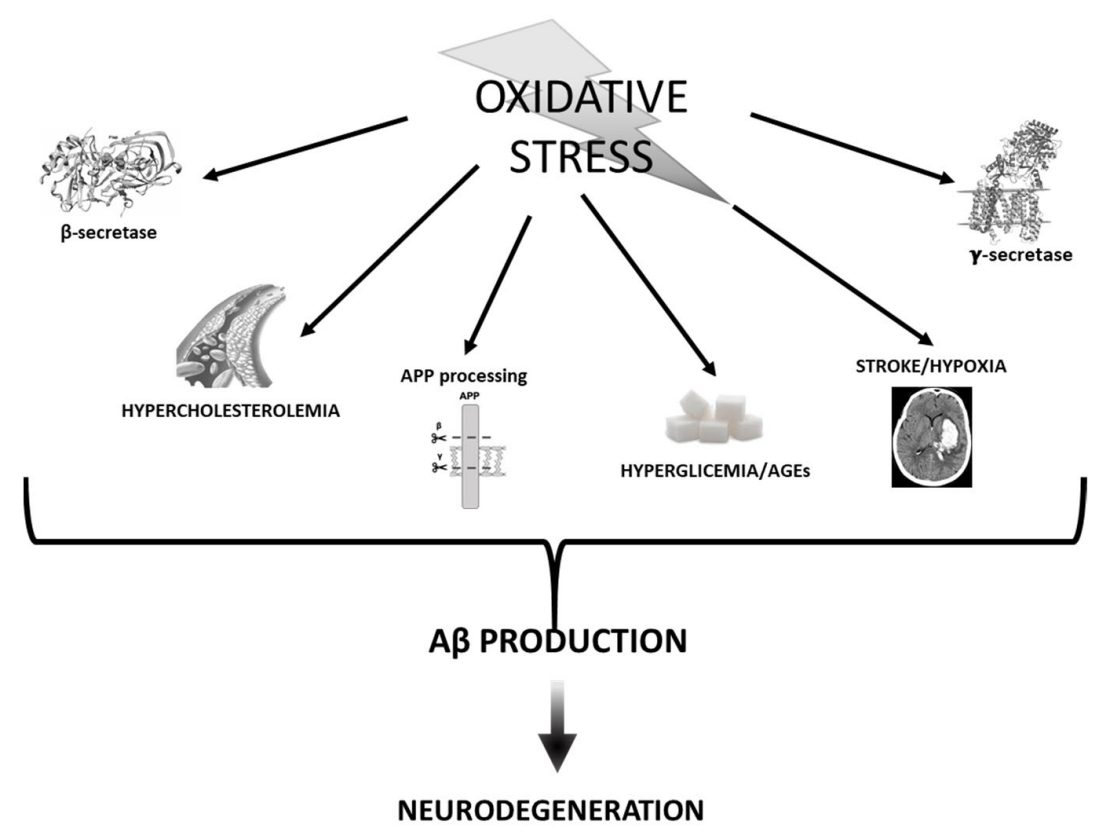

Figure 2. Diagram sketching mechanisms by which oxidative stress mediates $A \beta$ production.

\subsection{APP Processing and Secretases}

Many authors have confirmed the hypothesis that oxidative stress represents a common mechanism that mediates the accumulation and toxicity of $A \beta$ [103]. Therefore, oxidative stress can be considered one of the factors responsible for the accumulation of $A \beta$. Oxidizing agents increase the expression of APP [104] and increase the intracellular and secreted $A \beta$ levels [99]. We, along with other authors, have shown that the expression and activity of BACE 1 increased in conditions of oxidative stress [105-109]. Furthermore, there is a significant correlation between Bace1 activity and oxidative stress markers in brain tissues of sporadic AD [110] in which BACE1 levels have also been shown to significantly increased compared to normal aging [111,112].

Many authors proposed a sequence of events that observe oxidative stress, the hyperexpression of BACE1, and the induction of apoptosis connected with the deposition of $A \beta$. Thus, we have shown that oxidizing agents and HNE increase the expression and activity of BACE1 in neuronally differentiated cells, without modifying the levels of APP $[106,109,113]$. These events are followed by both $A \beta$ overproduction and apoptosis [114]

Furthermore, it has been shown that oxidative stress increases the activity of gamma secretase both in vitro and in vivo, and the increased expression of BACE1 induced by OS is regulated by gamma secretase $[115,116]$. These results are of great importance for 
understanding the pathogenesis of sporadic AD. First of all, it is shown that oxidative stress, which originates during aging, can increase the activity of both secretases ( $\beta$ and $\gamma$ secretases) and, thus, mediate the hyper production of $A \beta$. Oxidative stress is the only known factor capable of increasing the cut on APP operated by $\gamma$-secretase by increasing the activity of PS1, the catalytic subunit of secretase. These results demonstrate the existence of a vicious circle in which the increased activity of $\gamma$-secretase results in an increase in the expression of BACE 1 [117].

Other authors also demonstrated a correlation between the induction of OS and the increase in $\gamma$-secretase cleavage on APP [118-121]. Given that OS can mediate both $\gamma$-secretase and BACE1 activities, OS could be considered the molecular link between $\beta$-secretase and $\gamma$-secretase.

Another important consideration that closely links oxidative stress to the pathogenesis of $\mathrm{AD}$ is the fact that many of the best-known risk factors for sporadic AD observe oxidative stress playing a crucial role in their pathogenesis.

\subsection{Stroke and Hypoxia}

It is known in the literature that patients who have had strokes or cerebral infarction have an increased risk of developing AD [122].

The risk becomes even higher in the presence of atherosclerotic risk factors [123]. It has been proposed that hypoxia can alter the metabolism of APP, increasing the activity of $\beta$ and $\gamma$ secretase. Sun et al. demonstrated, for the first time, that hypoxia significantly increases the expression and activity of BACE1 [124]. Again, the same authors show that hypoxia increases the deposition of $\mathrm{A} \beta$ and the formation of senile plaques, and it also mediates mnemonic deficit, suggesting a mechanism capable of linking vascular damage with AD [125].

Hypoxia is also capable of increasing the activity of $\gamma$-secretase; thus, hypoxia inducible factor (HIF)- $1 \alpha$ binds the promoter of anteriorpharynx-defectivephenotype (APH-1), a key component of the secretase $\gamma$ complex, inducing its hyper regulation [125].

Taken together, these data show that hypoxia increases the activity of both secretases, thus resulting in an overproduction of $A \beta$ and the formation of plaques in both in vivo and in vitro models. It is well known that the only effective treatment for cerebral ischemic disease is the rapid restoration of the blood flow to the brain. However, reperfusion often aggravates brain injury, resulting in cerebral ischemia/reperfusion (I/R) injury [126]. The pathophysiological process underlying cerebral I/R injury is complex. Currently, intracellular $\mathrm{Ca}^{2+}$ overloading, oxygen free radical injury, excitatory amino acid toxicity, chemokines, and white blood cell interactions are considered to be underlying pathogenic factors that contribute to cerebral I/R injury [127].

It has also been shown that intracellular ROS levels change also during hypoxia; thus, ROS increases during hypoxia [128], and mitochondria would be their source of production under hypoxic conditions [128].

It is accepted that hypoxia increases ROS via the mitochondrial transport chain and specifically by the function of complex III [129].

Mitochondrial-derived ROS appears to be sufficient for stabilizing and activating HIF-1 $\alpha$, and it has been shown that antioxidant compounds can protect against this activation [130]. Recently, some anticancer effects of antioxidant drugs have been precisely ascribed to the protection of events mediated by the activation of HIF-1 $\alpha$ [131]. Guglielmotto et al. have shown that hypoxia induces a hyper regulation of BACE1 through two different mechanisms: by inducing an early release of ROS from the mitochondria and through a later activation of HIF-1 [132]. The crucial involvement of ROS released by mitochondria was confirmed by the complete protection exerted by rotenone, which alters the complex 1 of the mitochondrial electron transport chain [132].

\subsection{Hyperglycemia and AGEs}

Diabetes mellitus and hyperglycemia are other risks factor for AD [133]. 
Hyperglycemia enhances the formation of advanced glycation end products (AGEs), which are senescent protein derivatives from the auto-oxidation of glucose and fructose [134].

Accumulation of AGEs in various tissues is known to occur in normal aging and, at an extremely accelerated rate, in diabetes mellitus and renal failure [134]. AGEs have been detected in vascular walls, lipoproteins, and lipid constituents where they result in macro and microangiopathy and amyloidosis [135].

Increased extracellular AGEs formation was demonstrated in amyloid plaques in different cortical areas [136], where they may have a role in accelerating the conversion of $A \beta$ from monomers to oligomers or higher molecular weight forms.

In addition to post-translational protein modifications, AGEs have other pathologic effects at the cellular and molecular levels.

An increased presence of AGEs has been observed in amyloid plaques in various cerebral cortical areas [137], and their role has been demonstrated in accelerating the conversion of $\mathrm{A} \beta$ monomers into high molecular weight oligomers. In addition to inducing post-translational changes, AGEs induce toxicity at the molecular and cellular level through other mechanisms as well. These mechanisms also include the ability to induce oxidative stress, in particular, superoxide and hydrogen peroxide $[138,139]$. In fact, glycated proteins increase the production of free radicals compared to normal proteins. Another mechanism through which AGEs induce oxidative stress is through binding to their receptor (RAGE), a surface receptor belonging to the immunoglobulin superfamily [140].

RAGE is age-dependent hyper-regulated in human tissues [133], and the increased interaction between AGE and RAGE induces oxidative stress, which is crucial in the pathogenesis of many aging-related diseases, such as diabetes, cardiovascular disease, and AD [141].

The production of ROS induced by the interaction between AGEs and their receptor induces brain damage because it increases the vulnerability of the brain to oxidative stress. ROS increases the synthesis of $A \beta$, which induces the synthesis of high-mobility group box 1 (HMGB1), and S100. These molecules interact with RAGE, inducing a further production of oxygen free radicals that result in Alzheimer's disease. Therefore, the induction of oxidative stress precedes the formation of amyloid plaques. In conclusion, we can say that the disease begins with the stress induced by the interaction between AGE and RAGE, and A $\beta$, HMGB1, and S100 make it progress. The reduction in the levels of AGEs and RAGE, the increase in sRAGE, and the use of antioxidants could really have benefits in the prevention and in slowing down the progression of $\mathrm{AD}[142,143]$. $\mathrm{A} \beta$ extracellular fibrillar aggregates have characteristics of AGEs and bind to RAGE in neurons and brain endothelial cells. AGE and $A \beta$ binding to RAGEs results in further oxidative stress that contributes to neuronal death and vascular dementia in AD [144].

Although the brain was once considered an insulin-independent organ, insulin signalling is now recognised as being central to neuronal health and to the function of synapses and brain circuits [145]. Defective brain insulin signalling, as well as related signalling by insulin-like growth factor 1 (IGF-1), is associated with neurological disorders, including Alzheimer's disease, suggesting that cognitive impairment could be related to a state of brain insulin resistance [146]. A $\beta$ also regulates insulin and IGF signaling in the brain by binding to the insulin receptor and disrupting its signalling capacity in in vivo monkeys injected with oligomeric $A \beta$ [147]. In vitro studies showed that $A \beta$ decreases cell surface insulin receptor expression and promotes synaptic spine loss, one of the earliest structural defects observed in AD. Furthermore, insulin prevents $A \beta$ binding to the synapses preserving synaptic integrity [148]. Taken together, these findings suggest that AD pathological processes may be triggered or exacerbated by peripheral insulin resistance and that $A \beta$ may itself induce brain insulin resistance and synapse loss, raising the possibility that insulin treatment may correct these pathological events. Moreover, IGF-1 protects against hyperglycaemia-induced oxidative stress, and defective insulin signalling makes neurons more vulnerable to oxidative stress $[149,150]$. 
The fact that altered glucose metabolism precedes clinical symptoms strongly suggests that perturbed glucose homeostasis may be a cause rather than a consequence of $\mathrm{AD}$. In order to sustain neuroenergetics, brain glucose levels are tightly controlled by the glucose transporter, GLUT1, at the blood-brain barrier (BBB), and its expression is directly correlated with cerebrospinal fluid (CSF) glucose levels, brain development, and function [151,152]. Decreased GLUT1 expression at the BBB in AD brains has been reported [153,154]. Brain glucose enters glycolytic pathways to support its urgent and complex metabolic needs. For example, neurons utilize lactate from astrocytes to support their energy demands. This phenomenon, termed the astrocyte-to-neuron lactate shuttle (ANLS), was first described by Pellerin and Magistretti in the 1990s [155] and is supported by accumulating evidence [156,157]. Notably, increased lactate is associated with tau and A $\beta$ deposition, see review [158]. A human in vivo PET study revealed a spatial correlation between glycolysis and $A \beta$ deposition, suggesting a possible link between region-specific glycolysis in young brains and the subsequent development of AD pathology [159].

\subsection{Cholesterol}

Over the past decade, hypercholesterolemia, characterized by high blood levels of cholesterol, and obesity have been considered risk factors for the development of neurodegenerative diseases [160]. One of the mechanisms proposed to explain this correlation seems to be that high levels of cholesterol and free fatty acids result in incorrect regulation of lipid metabolism, which alters the permeability of BBB inducing neuroinflammation and cognitive deficits [161].

Evidence demonstrates the hypothesis that the oxidation of cholesterol plays a crucial role in the pathogenesis of $\mathrm{AD}$, and that oxysterols represent the link between $\mathrm{AD}$ and the alteration of lipid metabolism and hypercholesterolemia. The rationale for this hypothesis lies in the fact that oxysterols, unlike cholesterol, can cross the BBB. The key role of oxysterols in the pathogenesis of AD is suggested by studies that demonstrate their involvement in the modulation of neuroinflammation, in the accumulation of $A \beta$, and in the induction of cell death $[162,163]$.

\section{Concluding Remarks}

All data summarized in this review postulate that OS and $A \beta$ are linked to each other because $A \beta$ induces OS in vivo and in vitro, and OS increases the production of $A \beta$; for this reason, the answer to the question "did the chicken come before the egg?" remains, in our opinion, at least in part unsolved. Altogether, the evidence for the primary occurrence of oxidative stress in AD is very attractive and well supported. Zhu and colleagues, many years ago but still very relevant, have proposed a "Two-Hit" hypothesis whereby the early and progressive oxidative damage to neurons elicits a compensatory response such that the cell can exist in the overly oxidizing environment [164]. This "oxidative steady state", while initially instituted for protection, makes the cell vulnerable to additional insults, such as A $\beta$ deposition, NFT formation, cell cycle aberration, etc. [164]. More importantly, many of the above-mentioned hallmarks, in particular $A \beta$, are themselves the sources of oxidative stress. The overall effect is positive feedback.

Thus, whether the chicken or the egg comes first, oxidative stress certainly plays a very important role in the pathogenesis of Alzheimer's disease, and this lays the basis for clinical interventions in AD with antioxidants.

Endogenous antioxidants can protect against the production of free radicals and can mediate the expression of molecules that enhance the antioxidant action in neurons.

Several studies suggested an effectiveness of antioxidant enzymes such as superoxide dismutase (SOD) and catalase (CAT) in slowing the progression of $\mathrm{AD}$. In addition, various dietary antioxidants such as Vitamin E/C, curcumin, resveratrol, and Ginko biloba have emerged as promising agents in preclinical studies. However, the efficacy of antioxidants in clinical practice still leaves open questions. Thus, preclinical intervention with antioxidant molecules could be protective against AD, while their late use is useless [165]. 
Alzheimer's disease pathology begins many years before its symptoms; therefore, we must take advantage of this long window to modify and modulate all known risk factors for the disease. In this context, antioxidants can be an important weapon of prevention.

Funding: This research received no external funding.

Conflicts of Interest: The authors declare no conflict of interest.

\section{References}

1. Lane, C.A.; Hardy, J.; Schott, J.M. Alzheimer's disease. Eur. J. Neurol. 2018, 25, 59-70. [CrossRef]

2. Cummings, J.; Aisen, P.S.; DuBois, B.; Frölich, L.; Jack, C.R., Jr.; Jones, R.W.; Morris, J.C.; Raskin, J.; Dowsett, S.A.; Scheltens, P. Drug development in Alzheimer's disease: The path to 2025. Alzheimers Res Ther. 2016, 8, 39. [CrossRef] [PubMed]

3. Scheltens, P.; De Strooper, B.; Kivipelto, M.; Holstege, H.; Chételat, G.; Teunissen, C.; Cummings, J.; van der Flier, W.M. Alzheimer's disease. Lancet 2021, 397, 1577-1590. [CrossRef]

4. Long, J.M.; Holtzman, D.M. Alzheimer Disease: An Update on Pathobiology and Treatment Strategies. Cell 2019, 179, 312-339. [CrossRef] [PubMed]

5. Stöhr, J.; Watts, J.C.; Mensinger, Z.L.; Oehler, A.; Grillo, S.K.; DeArmond, S.J.; Prusiner, S.B.; Giles, K. Purified and synthetic Alzheimer's amyloid beta (A $\beta$ ) prions. Proc. Natl. Acad. Sci. USA 2012, 109, 11025-11030. [CrossRef]

6. Yu, H.; Wu, J. Amyloid- $\beta$ : A double agent in Alzheimer's disease? Biomed. Pharm. 2021, 139, 111575. [CrossRef]

7. Ji, C.; Sigurdsson, E.M. Current Status of Clinical Trials on Tau Immunotherapies. Drugs 2021, 8, 1135-1152. [CrossRef]

8. Xia, Y.; Prokop, S.; Giasson, B.I. "Don't Phos Over Tau": Recent developments in clinical biomarkers and therapies targeting tau phosphorylation in Alzheimer's disease and other tauopathies. Mol. Neurodegener. 2021, 16, 37. [CrossRef]

9. Mendez, M.F. Early-Onset Alzheimer Disease. Neurol. Clin. 2017, 35, 263-281. [CrossRef] [PubMed]

10. Haaksma, M.L.; Vilela, L.R.; Marengoni, A.; Calderón-Larrañaga, A.; Leoutsakos, J.S.; Olde Rikkert, M.G.M.; Melis, R.J.F. Comorbidity and progression of late onset Alzheimer's disease: A systematic review. PLoS ONE 2017, 12, e0177044.

11. Lemche, E. Early Life Stress and Epigenetics in Late-onset Alzheimer's Dementia: A Systematic Review. Curr. Genom. 2018, 19, 522-602. [CrossRef]

12. Zhou, X.; Fu, A.K.; Ip, N.Y. APOE signaling in neurodegenerative diseases: An integrative approach targeting APOE coding and noncoding variants for disease intervention. Curr. Opin. Neurobiol. 2021, 69, 58-67. [CrossRef]

13. Guglielmotto, M.; Repetto, I.E.; Monteleone, D.; Vasciaveo, V.; Franchino, C.; Rinaldi, S.; Tabaton, M.; Tamagno, E. Stroke and Amyloid- $\beta$ Downregulate TREM-2 and Uch-L1 Expression that Synergistically Promote the Inflammatory Response. J. Alzheimers Dis. 2019, 71, 907-920. [CrossRef]

14. Chen, M.J.; Ramesha, S.; Weinstock, L.D.; Gao, T.; Ping, L.; Xiao, H.; Dammer, E.B.; Duong, D.D.; Levey, A.I.; Lah, J.J.; et al. Extracellular signal-regulated kinase regulates microglial immune responses in Alzheimer's disease. J. Neurosci. Res. 2021, 99, 1704-1721. [CrossRef]

15. Bhattacherjee, A.; Jung, J.; Zia, S.; Ho, M.; Eskandari-Sedighi, G.; St Laurent, C.D.; McCord, K.A.; Bains, A.; Sidhu, G.; Sarkar, S.; et al. The CD33 short isoform is a gain-of-function variant that enhances A $\beta 1-42$ phagocytosis in microglia. Mol. Neurodegener. 2021, 16, 19. [CrossRef] [PubMed]

16. Mitsumori, R.; Sakaguchi, K.; Shigemizu, D.; Mori, T.; Akiyama, S.; Ozaki, K.; Niida, S.; Shimoda, N. Lower DNA methylation levels in CpG island shores of CR1, CLU, and PICALM in the blood of Japanese Alzheimer's disease patients. PLoS ONE 2020, 15, e0239196. [CrossRef] [PubMed]

17. Xu, W.; Tan, C.C.; Cao, X.P.; Tan, L. Alzheimer's Disease Neuroimaging Initiative. Association of Alzheimer's disease risk variants on the PICALM gene with PICALM expression, core biomarkers, and feature neurodegeneration. Aging 2020, 12, 21202-21219. [CrossRef] [PubMed]

18. Franzmeier, N.; Ossenkoppele, R.; Brendel, M.; Rubinski, A.; Smith, R.; Kumar, A.; Mattsson-Carlgren, N.; Strandberg, O.; Duerin, M.; Buerger, K.; et al. Alzheimer's Disease Neuroimaging Initiative (ADNI)* and the Swedish BioFINDER study. The BIN1 rs744373 Alzheimer's disease risk SNP is associated with faster A $\beta$-associated tau accumulation and cognitive decline. Alzheimers Dement. 2021. in print. [CrossRef] [PubMed]

19. Dib, S.; Pahnke, J.; Gosselet, F. Role of ABCA7 in Human Health and in Alzheimer's Disease. Int. J. Mol. Sci. 2021, 22, 4603. [CrossRef]

20. An, N.; Fu, Y.; Shi, J.; Guo, H.N.; Yang, Z.W.; Li, Y.C.; Li, S.; Wang, Y.; Yao, Z.J.; Hu, B. Alzheimer's Disease Neuroimaging Initiative. Synergistic Effects of APOE and CLU May Increase the Risk of Alzheimer's Disease: Acceleration of Atrophy in the Volumes and Shapes of the Hippocampus and Amygdala. J. Alzheimers Dis. 2021, 80, 1311-1327. [CrossRef]

21. Wälti, M.A.; Ravotti, F.; Arai, H.; Glabe, C.G.; Wall, J.S.; Böckmann, A.; Güntert, P.; Meier, B.H.; Riek, R. Atomic-resolution structure of a disease-relevant A $\beta(1-42)$ amyloid fibril. Proc. Natl. Acad. Sci. USA 2016, 113, E4976-E4984. [CrossRef]

22. Nguyen, K.V. The human $\beta$-amyloid precursor protein: Biomolecular and epigenetic aspects. Biomol. Concepts. 2015, 6, 11-32. [CrossRef] [PubMed]

23. Wilkins, H.M.; Swerdlow, R.H. Amyloid precursor protein processing and bioenergetics. Brain Res. Bull 2017, 133, 71-79. [CrossRef] [PubMed] 
24. Vassar, R.; Bennett, B.D.; Babu-Khan, S.; Kahn, S.; Mendiaz, E.A.; Denis, P.; Teplow, D.B.; Ross, S.; Amarante, P.; Loeloff, R.; et al. Beta-secretase cleavage of Alzheimer's amyloid precursor protein by the transmembrane aspartic protease BACE. Science 1999, 286, 735-741. [CrossRef]

25. Huse, J.T.; Doms, R.W. Closing in on the amyloid cascade: Recent insights into the cell biology of Alzheimer's disease. Mol. Neurobiol. 2000, 22, 81-98. [PubMed]

26. Sun, Z.T.; Ma, C.; Li, G.J.; Zheng, X.Y.; Hao, Y.T.; Yang, Y.; Wang, X. Application of Antibody Fragments Against A $\beta$ With Emphasis on Combined Application with Nanoparticles in Alzheimer's Disease. Front. Pharmacol. 2021, 12, 654611. [CrossRef] [PubMed]

27. Fagiani, F.; Lanni, C.; Racchi, M.; Govoni, S. (Dys)regulation of Synaptic Activity and Neurotransmitter Release by $\beta$-Amyloid: A Look Beyond Alzheimer's Disease Pathogenesis. Front. Mol. Neurosci. 2021, 14, 635880. [CrossRef]

28. Wang, K.; Na, L.; Duan, M. The Pathogenesis Mechanism, Structure Properties, Potential Drugs and Therapeutic Nanoparticles against the Small Oligomers of Amyloid- $\beta$. Curr. Top Med. Chem. 2021, 21, 151-167. [CrossRef] [PubMed]

29. Behl, T.; Kaur, I.; Fratila, O.; Brata, R.; Bungau, S. Exploring the Potential of Therapeutic Agents Targeted towards Mitigating the Events Associated with Amyloid- $\beta$ Cascade in Alzheimer's Disease. Int. J. Mol. Sci. 2020, 21, 7443. [CrossRef] [PubMed]

30. Decourt, B.; Boumelhem, F.; Pope, E.D., 3rd; Shi, J.; Mari, Z.; Sabbagh, M.N. Critical Appraisal of Amyloid Lowering Agents in AD. Curr. Neurol. Neurosci. Rep. 2021, 21, 39. [CrossRef]

31. Guo, T.; Zhang, D.; Zeng, Y.; Huang, T.Y.; Xu, H.; Zhao, Y. Molecular and cellular mechanisms underlying the pathogenesis of Alzheimer's disease. Mol. Neurodegener. 2020, 15, 40. [CrossRef]

32. Walsh, D.M.; Selkoe, D.J. Amyloid $\beta$-protein and beyond: The path forward in Alzheimer's disease. Curr. Opin. Neurobiol. 2020, 61, 116-124. [CrossRef] [PubMed]

33. Tabaton, M.; Gambetti, P. Soluble amyloid-beta in the brain: The scarlet pimpernel. J. Alzheimers Dis. 2006, 9, 127-132. [CrossRef]

34. Johannesson, M.; Sahlin, C.; Söderberg, L.; Basun, H.; Fälting, J.; Möller, C.; Zachrisson, O.; Sunnemark, D.; Svensson, A.; Odergren, T.; et al. Elevated soluble amyloid beta protofibrils in Down syndrome and Alzheimer's disease. Mol. Cell Neurosci. 2021, 114, 103641. [CrossRef] [PubMed]

35. Klyubin, I.; Walsh, D.M.; Lemere, C.A.; Cullen, W.K.; Shankar, G.M.; Betts, V.; Spooner, E.T.; Jiang, L.; Anwyl, R.; Selkoe, D.J.; et al. Amyloid beta protein immunotherapy neutralizes Abeta oligomers that disrupt synaptic plasticity in vivo. Nat. Med. 2005, 11, 556-561. [CrossRef] [PubMed]

36. Wei, Z.; Meng, X.; El Fatimy, R.; Sun, B.; Mai, D.; Zhang, J.; Arora, R.; Zeng, A.; Xu, P.; Qu, S.; et al. Environmental enrichment prevents $A \beta$ oligomer-induced synaptic dysfunction through mirna-132 and hdac3 signaling pathways. Neurobiol. Dis. 2020, 134, 104617. [CrossRef]

37. Koike, H.; Iguchi, Y.; Sahashi, K.; Katsuno, M. Significance of Oligomeric and Fibrillar Species in Amyloidosis: Insights into Pathophysiology and Treatment. Molecules 2021, 26, 5091. [CrossRef]

38. Morgan, D.; Diamond, D.M.; Gottschall, P.E.; Ugen, K.E.; Dickey, C.; Hardy, J.; Duff, K.; Jantzen, P.; DiCarlo, G.; Wilcock, D.; et al. A beta peptide vaccination prevents memory loss in an animal model of Alzheimer's disease. Nature 2000, 408, 982-985. [CrossRef]

39. Piccini, A.; Russo, C.; Gliozzi, A.; Relini, A.; Vitali, A.; Borghi, R.; Giliberto, L.; Armirotti, A.; D’Arrigo, C.; Bachi, A.; et al. beta-amyloid is different in normal aging and in Alzheimer disease. J. Biol. Chem. 2005, 280, 34186-34192. [CrossRef]

40. Lana, E.; Gellerbring, A.; Jung, S.; Nordberg, A.; Unger Lithner, C.; Darreh-Shori, T. Homomeric and Heteromeric A $\beta$ Species Exist in Human Brain and CSF Regardless of Alzheimer's Disease Status and Risk Genotype. Front. Mol. Neurosci. 2019, 12, 176. [CrossRef]

41. Di Fede, G.; Catania, M.; Maderna, E.; Ghidoni, R.; Benussi, L.; Tonoli, E.; Giaccone, G.; Moda, F.; Paterlini, A.; Campagnani, I.; et al. Molecular subtypes of Alzheimer's disease. Sci. Rep. 2018, 8, 3269. [CrossRef] [PubMed]

42. Li, S.; Jin, M.; Liu, L.; Dang, Y.; Ostaszewski, B.L.; Selkoe, D.J. Decoding the synaptic dysfunction of bioactive human AD brain soluble A $\beta$ to inspire novel therapeutic avenues for Alzheimer's disease. Acta Neuropathol. Commun. 2018, 6, 121. [CrossRef] [PubMed]

43. Haass, C.; Kaether, C.; Thinakaran, G.; Sisodia, S. Trafficking and proteolytic processing of APP. Cold Spring Harb. Perspect Med. 2012, 2, a006270. [CrossRef]

44. Chang, Y.T.; Chang, W.N.; Tsai, N.W.; Huang, C.C.; Kung, C.T.; Su, Y.J.; Lin, W.C.; Cheng, B.C.; Su, C.M.; Chiang, Y.F.; et al. The roles of biomarkers of oxidative stress and antioxidant in Alzheimer's disease: A systematic review. Biomed. Res. Int. 2014, 2014, 182303. [CrossRef]

45. Tofighi, N.; Asle-Rousta, M.; Rahnema, M.; Amini, R. Protective effect of alpha-linoleic acid on A $\beta$-induced oxidative stress, neuroinflammation, and memory impairment by alteration of $\alpha 7 \mathrm{nAChR}$ and NMDAR gene expression in the hippocampus of rats. Neurotoxicology 2021, 85, 245-253. [CrossRef]

46. Yang, X.; Zhi, J.; Leng, H.; Chen, Y.; Gao, H.; Ma, J.; Ji, J.; Hu, Q. The piperine derivative HJ105 inhibits A $\beta 1-42-i n d u c e d$ neuroinflammation and oxidative damage via the Keap1-Nrf2-TXNIP axis. Phytomedicine 2021, 20, 153571. [CrossRef] [PubMed]

47. Kimura, A.M.; Tsuji, M.; Yasumoto, T.; Mori, Y.; Oguchi, T.; Tsuji, Y.; Umino, M.; Umino, A.; Nishikawa, T.; Nakamura, S.; et al. Myricetin prevents high molecular weight A $\beta 1-42$ oligomer-induced neurotoxicity through antioxidant effects in cell membranes and mitochondria. Free Radic. Biol. Med. 2021, 171, 232-244. [CrossRef] [PubMed] 
48. Meng, M.; Zhang, L.; Ai, D.; Wu, H.; Peng, W. $\beta$-Asarone Ameliorates $\beta$-Amyloid-Induced Neurotoxicity in PC12 Cells by Activating P13K/Akt/Nrf2 Signaling Pathway. Front. Pharmacol. 2021, 12, 659955. [CrossRef] [PubMed]

49. Tamagno, E.; Robino, G.; Obbili, A.; Bardini, P.; Aragno, M.; Parola, M.; Danni, O. $\mathrm{H}_{2} \mathrm{O}_{2}$ and 4-hydroxynonenal mediate amyloid beta-induced neuronal apoptosis by activating JNKs and p38MAPK. Exp. Neurol. 2003, 180, 144-155. [CrossRef]

50. Zuo, L.; Hemmelgarn, B.T.; Chuang, C.C.; Best, T.M. The Role of Oxidative Stress-Induced Epigenetic Alterations in Amyloid- $\beta$ Production in Alzheimer's Disease. Oxid. Med. Cell Longev. 2015, 2015, 604658. [CrossRef]

51. Bhatia, V.; Sharma, S. Role of mitochondrial dysfunction, oxidative stress and autophagy in progression of Alzheimer's disease. J. Neurol. Sci. 2021, 421, 117253. [CrossRef] [PubMed]

52. Picone, P.; Nuzzo, D.; Caruana, L.; Scafidi Di Carlo, M. Mitochondrial dysfunction: Different routes to Alzheimer's disease therapy. Oxid. Med. Cell Longev. 2014, 2014, 780179. [CrossRef]

53. Desler, C.; Lillenes, M.S.; Tønjum, T.; Rasmussen, L.J. The Role of Mitochondrial Dysfunction in the Progression of Alzheimer's Disease. Curr. Med. Chem. 2018, 25, 5578-5587. [CrossRef] [PubMed]

54. Anantharaman, M.; Tangpong, J.; Keller, J.N.; Murphy, M.P.; Markesbery, W.R.; Kiningham, K.K.; St Clair, D.K. Beta-amyloid mediated nitration of manganese superoxide dismutase: Implication for oxidative stress in a APPNLH/NLH X PS-1P264L/P264L double knock-in mouse model of Alzheimer's disease. Am. J. Pathol. 2006, 168, 1608-1618. [CrossRef] [PubMed]

55. Sen, A.; Nelson, T.J.; Alkon, D.L.; Hongpaisan, J. Loss in PKC Epsilon Causes Downregulation of MnSOD and BDNF Expression in Neurons of Alzheimer's Disease Hippocampus. J. Alzheimers Dis. 2018, 63, 1173-1189. [CrossRef]

56. Yao, J.; Du, H.; Yan, S.; Fang, F.; Wang, C.; Lue, L.F.; Guo, L.; Chen, D.; Stern, D.M.; Gunn Moore, F.J.; et al. Inhibition of amyloid-beta (Abeta) peptide-binding alcohol dehydrogenase-Abeta interaction reduces Abeta accumulation and improves mitochondrial function in a mouse model of Alzheimer's disease. J. Neurosci. 2011, 31, 2313-2320. [CrossRef]

57. Nikolac Perkovic, M.; Videtic Paska, A.; Konjevod, M.; Kouter, K.; Svob Strac, D.; Nedic Erjavec, G.; Pivac, N. Epigenetics of Alzheimer's Disease. Biomolecules 2021, 11, 195. [CrossRef] [PubMed]

58. Swerdlow, R.H.; Burns, J.M.; Khan, S.M. The Alzheimer's disease mitochondrial cascade hypothesis: Progress and perspectives. Biochim. Biophys. Acta 2014, 1842, 1219-1231. [CrossRef]

59. Detaille, D.; Pasdois, P.; Sémont, A.; Dos Santos, P.; Diolez, P. An old medicine as a new drug to prevent mitochondrial complex I from producing oxygen radicals. PLoS ONE 2019, 14, e0216385. [CrossRef]

60. Bennett, J.P. Medical hypothesis: Neurodegenerative diseases arise from oxidative damage to electron tunneling proteins in mitochondria. Med. Hypotheses 2019, 127, 1-4. [CrossRef]

61. Qi, Z.; Liu, K.J. The interaction of zinc and the blood-brain barrier under physiological and ischemic conditions. Toxicol. Appl. Pharmacol. 2019, 364, 114-119. [CrossRef] [PubMed]

62. Duck, K.A.; Connor, J.R. Iron uptake and transport across physiological barriers. Biometals 2016, 29, 573-591. [CrossRef] [PubMed]

63. Lovell, M.A.; Robertson, J.D.; Teesdale, W.J.; Campbell, J.L.; Markesbery, W.R. Copper, iron and zinc in Alzheimer's disease senile plaques. J. Neurol. Sci. 1998, 158, 47-52. [CrossRef]

64. Huang, X.; Atwood, C.S.; Hartshorn, M.A.; Multhaup, G.; Goldstein, L.E.; Scarpa, R.C.; Cuajungco, M.P.; Gray, D.N.; Lim, J.; Moir, R.D.; et al. The A beta peptide of Alzheimer's disease directly produces hydrogen peroxide through metal ion reduction. Biochemistry 1999, 38, 7609-7616. [CrossRef] [PubMed]

65. Banerjee, P.; Sahoo, A.; Anand, S.; Ganguly, A.; Righi, G.; Bovicelli., P.; Saso, L.; Chakrabarti, S. Multiple mechanisms of iron-induced amyloid beta-peptide accumulation in SHSY5Y cells: Protective action of negletein. Neuromolecular Med. 2014, 16, 787-798. [CrossRef]

66. Suh, S.W.; Jensen, K.B.; Jensen, M.S.; Silva, D.S.; Kesslak, P.J.; Danscher, G.; Frederickson, C.J. Histochemically-reactive zinc in amyloid plaques, angiopathy, and degenerating neurons of Alzheimer's diseased brains. Brain Res. 2000, 852, 274-278. [CrossRef]

67. Zhang, L.H.; Wang, X.; Zheng, Z.H.; Ren, H.; Stoltenberg, M.; Danscher, G.; Huang, L.; Rong, M.; Wang, Z.Y. Altered expression and distribution of zinc transporters in APP/PS1 transgenic mouse brain. Neurobiol. Aging 2010, 31, 74-87. [CrossRef]

68. Lee, M.C.; Yu, W.C.; Shih, Y.H.; Chen, C.Y.; Guo, Z.H.; Huang, S.J.; Chan, J.C.C.; Chen, Y.R. Zinc ion rapidly induces toxic, off-pathway amyloid- $\beta$ oligomers distinct from amyloid- $\beta$ derived diffusible ligands in Alzheimer's disease. Sci. Rep. 2018, 8, 4772. [CrossRef] [PubMed]

69. Hooda, J.; Shah, A.; Zhang, L. Heme, an essential nutrient from dietary proteins, critically impacts diverse physiological and pathological processes. Nutrients 2014, 6, 1080-1102. [CrossRef]

70. Faux, N.G.; Rembach, A.; Wiley, J.; Ellis, K.A.; Ames, D.; Fowler, C.J.; Martins, R.N.; Pertile, K.K.; Rumble, R.L.; Trounson, B.; et al. An anemia of Alzheimer's disease. Mol. Psychiatry 2014, 19, 1227-1234. [CrossRef] [PubMed]

71. Gozzelino, R. The Pathophysiology of Heme in the Brain. Curr. Alzheimer Res. 2016, 13, 174-184. [CrossRef]

72. Vanacore, R.; Eskew, J.D.; Sung, L.; Davis, T.; Smith, A. Safe coordinated trafficking of heme and iron with copper maintain cell homeostasis: Modules from the hemopexin system. Biometals 2019, 2, 355-367. [CrossRef]

73. Sankar, S.B.; Donegan, R.K.; Shah, K.J.; Reddi, A.R.; Wood, L.B. Heme and hemoglobin suppress amyloid $\beta$-mediated inflammatory activation of mouse astrocytes. J. Biol. Chem. 2018, 293, 11358-11373. [CrossRef]

74. Atamna, H. Heme binding to Amyloid-beta peptide: Mechanistic role in Alzheimer's disease. J. Alzheimers Dis. 2006, 10, 255-266. [CrossRef]

75. Atamna, H.; Liu, J.; Ames, B.N. Heme deficiency selectively interrupts assembly of mitochondrial complex IV in human fibroblasts: Revelance to aging. J. Biol. Chem. 2001, 276, 48410-48416. [CrossRef] 
76. Ghosh, C.; Seal, M.; Mukherjee, S.; Ghosh Dey, S. Alzheimer's Disease: A Heme-A $\beta$ Perspective. Acc. Chem. Res. 2015, 48, 2556-2564. [CrossRef]

77. Ganguly, U.; Kaur, U.; Chakrabarti, S.S.; Sharma, P.; Agrawal, B.K.; Saso, L.; Chakrabarti, S. Oxidative Stress, Neuroinflammation, and NADPH Oxidase: Implications in the Pathogenesis and Treatment of Alzheimer's Disease. Oxid. Med. Cell Longev. 2021, 2021, 7086512. [CrossRef] [PubMed]

78. Frost, G.R.; Jonas, L.A.; Li, Y.M. Friend, Foe or Both? Immune Activity in Alzheimer's Disease. Front. Aging Neurosci. 2019, 11, 337. [CrossRef] [PubMed]

79. Leng, F.; Edison, P. Neuroinflammation and microglial activation in Alzheimer disease: Where do we go from here? Nat. Rev. Neurol. 2021, 17, 157-172. [CrossRef] [PubMed]

80. Villa, V.; Thellung, S.; Bajetto, A.; Gatta, E.; Robello, M.; Novelli, F.; Tasso, B.; Tonelli, M.; Florio, T. Novel celecoxib analogues inhibit glial production of prostaglandin E2, nitric oxide, and oxygen radicals reverting the neuroinflammatory responses induced by misfolded prion protein fragment 90-231 or lipopolysaccharide. Pharmacol. Res. 2016, 113, 500-514. [CrossRef]

81. Rostami, J.; Mothes, T.; Kolahdouzan, M.; Eriksson, O.; Moslem, M.; Bergström, J.; Ingelsson, M.; O'Callaghan, P.; Healy, L.M.; Falk, A.; et al. Crosstalk between astrocytes and microglia results in increased degradation of $\alpha$-synuclein and amyloid- $\beta$ aggregates. J. Neuroinflamm. 2021, 18, 124. [CrossRef]

82. Brosseron, F.; Krauthausen, M.; Kummer, M.; Heneka, M.T. Body fluid cytokine levels in mild cognitive impairment and Alzheimer's disease: A comparative overview. Mol. Neurobiol. 2014, 50, 534-544. [CrossRef] [PubMed]

83. Cribbs, D.H.; Berchtold, N.C.; Perreau, V.; Coleman, P.D.; Rogers, J.; Tenner, A.J.; Cotman, C.W. Extensive innate immune gene activation accompanies brain aging, increasing vulnerability to cognitive decline and neurodegeneration: A microarray study. $J$. Neuroinflamm. 2012, 9, 179. [CrossRef] [PubMed]

84. Xiang, Z.; Haroutunian, V.; Ho, L.; Purohit, D.; Pasinetti, G.M. Microglia activation in the brain as inflammatory biomarker of Alzheimer's disease neuropathology and clinical dementia. Dis. Markers 2006, 22, 95-102. [CrossRef] [PubMed]

85. Martínez Leo, E.E.; Segura Campos, M.R. Systemic Oxidative Stress: A key Point in Neurodegeneration-A Review. J. Nutr. Health Aging 2019, 23, 694-699. [CrossRef]

86. Ashour, N.H.; El-Tanbouly, D.M.; El Sayed, N.S.; Khattab, M.M. Roflumilast ameliorates cognitive deficits in a mouse model of amyloidogenesis and tauopathy: Involvement of nitric oxide status, A $\beta$ extrusion transporter ABCB1, and reversal by PKA inhibitor H89. Prog. Neuropsychopharmacol. Biol. Psychiatry 2021, 111, 110366. [CrossRef]

87. Xu, J.J.; Guo, S.; Xue, R.; Xiao, L.; Kou, J.N.; Liu, Y.Q.; Han, J.Y.; Fu, J.J.; Wei, N. Adalimumab ameliorates memory impairments and neuroinflammation in chronic cerebral hypoperfusion rats. Aging 2021, 13, 14001-14014. [CrossRef]

88. Saresella, M.; La Rosa, F.; Piancone, F.; Zoppis, M.; Marventano, I.; Calabrese, E.; Rainone, V.; Nemni, R.; Mancuso, R.; Clerici, M. The NLRP3 and NLRP1 inflammasomes are activated in Alzheimer's disease. Mol. Neurodegener 2016, 11, 23. [CrossRef]

89. Zhang, Y.; Zhao, Y.; Zhang, J.; Yang, G. Mechanisms of NLRP3 Inflammasome Activation: Its Role in the Treatment of Alzheimer's Disease. Neurochem. Res. 2020, 45, 2560-2572. [CrossRef]

90. Hanslik, K.L.; Ulland, T.K. The Role of Microglia and the Nlrp3 Inflammasome in Alzheimer's Disease. Front. Neurol. 2020, 11, 570711. [CrossRef]

91. Chiu, Y.J.; Lin, C.H.; Lee, M.C.; Hsieh-Li, H.M.; Chen, C.M.; Wu, Y.R.; Chang, K.H.; Lee-Chen, G.J. Formulated Chinese medicine Shaoyao Gancao Tang reduces NLRP1 and NLRP3 in Alzheimer's disease cell and mouse models for neuroprotection and cognitive improvement. Aging 2021, 9, 13.

92. Jha, N.K.; Jha, S.K.; Kar, R.; Nand, P.; Swati, K.; Goswami, V.K. Nuclear factor-kappa $\beta$ as a therapeutic target for Alzheimer's disease. J. Neurochem. 2019, 150, 113-137. [CrossRef]

93. Ji, Y.; Han, J.; Lee, N.; Yoon, J.H.; Youn, K.; Ha, H.J.; Yoon, E.; Kim, D.H.; Jun, M. Neuroprotective Effects of Baicalein, Wogonin, and Oroxylin A on Amyloid Beta-Induced Toxicity via NF-kB/MAPK Pathway Modulation. Molecules 2020, 25, 5087. [CrossRef]

94. Youn, K.; Jun, M. Geraniin Protects PC12 Cells Against A $325-35-$ Mediated Neuronal Damage: Involvement of NF- $\mathrm{kB}$ and MAPK Signaling Pathways. J. Med. Food 2020, 23, 928-937. [CrossRef]

95. Ma, L.Y.; Liu, S.F.; Du, J.H.; Niu, Y.; Hou, P.F.; Shu, Q.; Ma, R.R.; Wu, S.D.; Qu, Q.M.; Lv, Y.L. Chronic ghrelin administration suppresses IKK/NF- $\mathrm{B} / \mathrm{BACE} 1$ mediated $\mathrm{A} \beta$ production in primary neurons and improves cognitive function via upregulation of PP1 in STZ-diabetic rats. Neurobiol. Learn Mem. 2020, 169, 107155. [CrossRef] [PubMed]

96. Cutler, R.G.; Kelly, J.; Storie, K.; Pedersen, W.A.; Tammara, A.; Hatanpaa, K.; Troncoso, J.C.; Mattson, M.P. Involvement of oxidative stress-induced abnormalities in ceramide and cholesterol metabolism in brain aging and Alzheimer's disease. Proc. Natl. Acad. Sci. USA 2004, 101, 2070-2075. [CrossRef]

97. Arimon, M.; Takeda, S.; Post, K.; Svirsky, S.; Hyman, B.T.; Berezovska, O. Oxidative stress and lipid peroxidation are upstream of amyloid pathology. Neurobiol. Dis. 2015, 84, 109-119. [CrossRef] [PubMed]

98. Perry, G.; Nunomura, A.; Hirai, K.; Takeda, A.; Aliev, G.; Smith, M.A. Oxidative damage in Alzheimer's disease: The metabolic dimension. Int. J. Dev. Neurosci. 2000, 18, 417-421. [CrossRef]

99. Butterfield, D.A.; Castegna, A. Proteomic analysis of oxidatively modified proteins in Alzheimer's disease brain: Insights into neurodegeneration. Cell Mol. Biol. 2003, 49, 747-751.

100. Butterfield, D.A.; Gnjec, A.; Poon, H.F.; Castegna, A.; Pierce, W.M.; Klein, J.B.; Martins, R.N. Redox proteomics identification of oxidatively modified brain proteins in inherited Alzheimer's disease: An initial assessment. J. Alzheimers Dis. 2006, 10, 391-397. [CrossRef] 
101. Huang, X.; Zhao, X.; Li, B.; Cai, Y.; Zhang, S.; Yu, F.; Wan, Q. Biomarkers for evaluating the effects of exercise interventions in patients with MCI or dementia: A systematic review and meta-analysis. Exp. Gerontol. 2021, 151, 111424. [CrossRef]

102. Karisetty, B.C.; Bhatnagar, A.; Armour, E.M.; Beaver, M.; Zhang, H.; Elefant, F. Amyloid- $\beta$ Peptide Impact on Synaptic Function and Neuroepigenetic Gene Control Reveal New Therapeutic Strategies for Alzheimer's Disease. Front. Mol. Neurosci. 2020, 13, 577622. [CrossRef]

103. Saeedi, M.; Rashidy-Pour, A. Association between chronic stress and Alzheimer's disease: Therapeutic effects of Saffron. Biomed. Pharmacother. 2021, 133, 110995. [CrossRef]

104. McCarty, M.F.; DiNicolantonio, J.J.; Lerner, A. A Fundamental Role for Oxidants and Intracellular Calcium Signals in Alzheimer's Pathogenesis-And How a Comprehensive Antioxidant Strategy May Aid Prevention of This Disorder. Int. J. Mol. Sci. 2021, 22, 2140. [CrossRef]

105. Patil, S.; Sheng, L.; Masserang, A.; Chan, C. Palmitic acid-treated astrocytes induce BACE1 upregulation and accumulation of C-terminal fragment of APP in primary cortical neurons. Neurosci. Lett. 2006, 406, 55-59. [CrossRef] [PubMed]

106. Hernández-Rodríguez, M.; Arciniega-Martínez, I.M.; García-Marín, I.D.; Correa-Basurto, J.; Rosales-Hernández, M.C. Chronic Administration of Scopolamine Increased GSK3 $\beta$ P9, Beta Secretase, Amyloid Beta, and Oxidative Stress in the Hippocampus of Wistar Rats. Mol. Neurobiol. 2020, 57, 3979-3988. [CrossRef]

107. Tamagno, E.; Bardini, P.; Obbili, A.; Vitali, A.; Borghi, R.; Zaccheo, D.; Pronzato, M.A.; Danni, O.; Smith, M.A.; Perry, G.; et al. Oxidative stress increases expression and activity of BACE in NT2 neurons. Neurobiol. Dis. 2002, 10, 279-288. [CrossRef]

108. Tong, Y.; Zhou, W.; Fung, V.; Christensen, M.A.; Qing, H.; Sun, X.; Song, W. Oxidative stress potentiates BACE1 gene expression and Abeta generation. J. Neural. Transm. 2005, 112, 455-469. [CrossRef] [PubMed]

109. Zhang, J.S.; Zhou, S.F.; Wang, Q.; Guo, J.N.; Liang, H.M.; Deng, J.B.; He, W.Y. Gastrodin suppresses BACE1 expression under oxidative stress condition via inhibition of the PKR/eIF2 $\alpha$ pathway in Alzheimer's disease. Neuroscience 2016, 25, 1-9. [CrossRef]

110. Syeda, T.; Cannon, J.R. Environmental exposures and the etiopathogenesis of Alzheimer's disease: The potential role of BACE1 as a critical neurotoxic target. J. Biochem. Mol. Toxicol. 2021, 35, e22694. [CrossRef] [PubMed]

111. Borghi, R.; Patriarca, S.; Traverso, N.; Piccini, A.; Storace, D.; Garuti, A.; Cirmena, G.; Odetti, P.; Tabaton, M. The increased activity of BACE1 correlates with oxidative stress in Alzheimer's disease. Neurobiol. Aging 2007, 28, 1009-1014. [CrossRef] [PubMed]

112. Fukumoto, H.; Cheung, B.S.; Hyman, B.T.; Irizarry, M.C. Beta-secretase protein and activity are increased in the neocortex in Alzheimer disease. Arch. Neurol. 2002, 59, 1381-1389. [CrossRef] [PubMed]

113. Sun, X.; Bromley-Brits, K.; Song, W. Regulation of $\beta$-site APP-cleaving enzyme 1 gene expression and its role in Alzheimer's disease. J. Neurochem. 2012, 120, 62-70. [CrossRef]

114. Tamagno, E.; Guglielmotto, M.; Bardini, P.; Santoro, G.; Davit, A.; Di Simone, D.; Danni, O.; Tabaton, M. Dehydroepiandrosterone reduces expression and activity of BACE in NT2 neurons exposed to oxidative stress. Neurobiol. Dis. 2003, 14, 291-301. [CrossRef]

115. Tamagno, E.; Parola, M.; Bardini, P.; Piccini, A.; Borghi, R.; Guglielmotto, M.; Santoro, G.; Davit, A.; Danni, O.; Smith, M.A.; et al. Beta-site APP cleaving enzyme up-regulation induced by 4-hydroxynonenal is mediated by stress-activated protein kinases pathways. J. Neurochem. 2005, 92, 628-636. [CrossRef]

116. Tamagno, E.; Guglielmotto, M.; Aragno, M.; Borghi, R.; Autelli, R.; Giliberto, L.; Muraca, G.; Danni, O.; Zhu, X.; Smith, M.A.; et al. Oxidative stress activates a positive feedback between the gamma- and beta-secretase cleavages of the beta-amyloid precursor protein. J. Neurochem. 2008, 104, 683-695.

117. Jo, D.G.; Arumugam, T.V.; Woo, H.N.; Park, J.S.; Tang, S.C.; Mughal, M.; Hyun, D.H.; Park, J.-H.; Choi, Y.H.; Gwon, A.R.; et al. Evidence that gamma-secretase mediates oxidative stress-induced beta-secretase expression in Alzheimer's disease. Neurobiol. Aging 2010, 31, 917-925. [CrossRef]

118. Giliberto, L.; Borghi, R.; Piccini, A.; Mangerini, R.; Sorbi, S.; Cirmena, G.; Garuti, A.; Ghetti, B.; Tagliavini, F.; Mughal, M.R.; et al. Mutant presenilin 1 increases the expression and activity of BACE1. J. Biol. Chem. 2009, 284, 9027-9038. [CrossRef]

119. Jin, S.M.; Cho, H.J.; Jung, E.S.; Shim, M.Y.; Mook-Jung, I. DNA damage-inducing agents elicit gamma-secretase activation mediated by oxidative stress. Cell Death Differ. 2008, 15, 1375-1384. [CrossRef]

120. Sheng, B.; Gong, K.; Niu, Y.; Liu, L.; Yan, Y.; Lu, G.; Zhang, L.; Hu, M.; Zhao, N.; Zhang, X.; et al. Inhibition of gamma-secretase activity reduces Abeta production, reduces oxidative stress, increases mitochondrial activity and leads to reduced vulnerability to apoptosis: Implications for the treatment of Alzheimer's disease. Free Radic. Biol. Med. 2009, 46, 1362-1375. [CrossRef]

121. Masand, N.; Gupta, S.P.; Khosa, R.L. Designing of Selective $\gamma$-Secretase Inhibitory Benzenesulfonamides through Comparative In Vitro and In Silico Analysis. Curr. Drug Discov. Technol. 2018, 15, 65-77. [CrossRef] [PubMed]

122. Zhou, J.; Yu, J.T.; Wang, H.F.; Meng, X.F.; Tan, C.C.; Wang, J.; Wang, C.; Tan, L. Association between stroke and Alzheimer's disease: Systematic review and meta-analysis. J. Alzheimers Dis. 2015, 43, 479-489. [CrossRef] [PubMed]

123. Shabir, O.; Berwick, J.; Francis, S.E. Neurovascular dysfunction in vascular dementia, Alzheimer's and atherosclerosis. BMC Neurosci. 2018, 19, 62. [CrossRef]

124. Sun, X.; He, G.; Qing, H.; Zhou, W.; Dobie, F.; Cai, F.; Staufenbiel, M.; Huang, L.E.; Song, W. Hypoxia facilitates Alzheimer's disease pathogenesis by up-regulating BACE1 gene expression. Proc. Natl. Acad. Sci. USA 2006, 103, 18727-18732. [CrossRef]

125. Li, L.; Zhang, X.; Yang, D.; Luo, G.; Chen, S.; Le, W. Hypoxia increases Abeta generation by altering beta- and gamma-cleavage of APP. Neurobiol. Aging 2009, 30, 1091-1098. [CrossRef] [PubMed]

126. Kalogeris, T.; Baines, C.P.; Krenz, M.; Korthuis, R.J. Cell biology of ischemia/reperfusion injury. Int. Rev. Cell Mol. Biol. 2012, 298, 229-317. 
127. Peers, C.; Pearson, H.A.; Boyle, J.P. Hypoxia and Alzheimer's disease. Essays Biochem. 2007, 43, 153-164. [CrossRef]

128. Burtscher, J.; Mallet, R.T.; Burtscher, M.; Millet, G.P. Hypoxia and brain aging: Neurodegeneration or neuroprotection? Ageing Res. Rev. 2021, 68, 101343. [CrossRef]

129. Guzy, R.D.; Mack, M.M.; Schumacker, P.T. Mitochondrial complex III is required for hypoxia-induced ROS production and gene transcription in yeast. Antioxid. Redox Signal. 2007, 9, 1317-1328. [CrossRef]

130. Zhang, Z.; Yan, J.; Chang, Y.; ShiDu Yan, S.; Shi, H. Hypoxia inducible factor-1 as a target for neurodegenerative diseases. Curr. Med. Chem. 2011, 18, 4335-4343. [CrossRef]

131. Paredes, F.; Williams, H.C.; San Martin, A. Metabolic adaptation in hypoxia and cancer. Cancer Lett. 2021, 502, 133-142. [CrossRef]

132. Guglielmotto, M.; Aragno, M.; Autelli, R.; Giliberto, L.; Novo, E.; Colombatto, S.; Danni, O.; Parola, M.; Smith, M.A.; Perry, G.; et al. The up-regulation of BACE1 mediated by hypoxia and ischemic injury: Role of oxidative stress and HIF1alpha. J. Neurochem. 2009, 108, 1045-1056. [CrossRef]

133. Diniz Pereira, J.; Gomes Fraga, V.; Morais Santos, A.L.; Carvalho, M.D.G.; Caramelli, P.; Braga Gomes, K. Alzheimer's disease and type 2 diabetes mellitus: A systematic review of proteomic studies. J. Neurochem. 2021, 156, 753-776. [CrossRef]

134. Wu, X.Q.; Zhang, D.D.; Wang, Y.N.; Tan, Y.Q.; Yu, X.Y.; Zhao, Y.Y. AGE/RAGE in diabetic kidney disease and ageing kidney. Free Radic. Biol. Med. 2021, 171, 260-271. [CrossRef]

135. Iannuzzi, C.; Irace, G.; Sirangelo, I. Differential effects of glycation on protein aggregation and amyloid formation. Front. Mol. Biosci. 2014, 1, 9. [CrossRef] [PubMed]

136. Fawver, J.N.; Schall, H.E.; Petrofes Chapa, R.D.; Zhu, X.; Murray, I.V. Amyloid- $\beta$ metabolite sensing: Biochemical linking of glycation modification and misfolding. J. Alzheimers Dis. 2012, 30, 63-73. [CrossRef] [PubMed]

137. Muscat, S.; Pelka, J.; Hegele, J.; Weigle, B.; Münch, G.; Pischetsrieder, M. Coffee and Maillard products activate NF-kappaB in macrophages via $\mathrm{H} 2 \mathrm{O} 2$ production. Mol. Nutr. Food Res. 2007, 51, 525-535. [CrossRef]

138. Hu, Z.; Fang, W.; Liu, Y.; Liang, H.; Chen, W.; Wang, H. Acute glucose fluctuation promotes RAGE expression via reactive oxygen species-mediated NF-KB activation in rat podocytes. Mol. Med. Rep. 2021, 23, 330. [CrossRef] [PubMed]

139. Prasad, K. AGE-RAGE stress: A changing landscape in pathology and treatment of Alzheimer's disease. Mol. Cell Biochem. 2019, 459, 95-112. [CrossRef] [PubMed]

140. Fleming, T.H.; Humpert, P.M.; Nawroth, P.P.; Bierhaus, A. Reactive metabolites and AGE/RAGE-mediated cellular dysfunction affect the aging process: A mini-review. Gerontology 2011, 57, 435-443. [CrossRef]

141. Prasad, K. AGE-RAGE stress play a role in aortic aneurysm: A comprehensive review and novel potential therapeutic target. Rev. Cardiovasc. Med. 2019, 20, 201-208.

142. Ramasamy, R.; Yan, S.F.; Schmidt, A.M. Receptor for AGE (RAGE): Signaling mechanisms in the pathogenesis of diabetes and its complications. Ann. N. Y. Acad. Sci. 2011, 1243, 88-102. [CrossRef] [PubMed]

143. Campora, M.; Francesconi, V.; Schenone, S.; Tasso, B.; Tonelli, M. Journey on Naphthoquinone and Anthraquinone Derivatives: New Insights in Alzheimer's Disease. Pharmaceuticals 2021, 14, 33. [CrossRef] [PubMed]

144. Samant, N.P.; Gupta, G.L. Novel therapeutic strategies for Alzheimer's disease targeting brain cholesterol homeostasis. Eur. J. Neurosci. 2021, 53, 673-686. [CrossRef]

145. Butterfield, D.A.; Halliwell, B. Oxidative stress, dysfunctional glucose metabolism and Alzheimer disease. Nat. Rev. Neurosci. 2019, 20, 148-160. [CrossRef] [PubMed]

146. Ribe, E.M.; Lovestone, S. Insulin signalling in Alzheimer's disease and diabetes: From epidemiology to molecular links. J. Intern Med. 2016, 280, 430-442. [CrossRef]

147. Bomfim, T.R.; Forny-Germano, L.; Sathler, L.B.; Brito-Moreira, J.; Houzel, J.C.; Decker, H.; Silverman, M.A.; Kazi, H.; Melo, H.M.; McClean, P.L.; et al. An anti-diabetes agent protects the mouse brain from defective insulin signaling caused by Alzheimer's disease- associated A $\beta$ oligomers. J. Clin. Investig. 2012, 122, 1339-13353. [CrossRef]

148. Blázquez, E.; Velázquez, E.; Hurtado-Carneiro, V.; Ruiz-Albusac, J.M. Insulin in the brain: Its pathophysiological implications for States related with central insulin resistance, type 2 diabetes and Alzheimer's disease. Front. Endocrinol. 2014, 5, 161. [CrossRef]

149. Loh, K.; Deng, H.; Fukushima, A.; Cai, X.; Boivin, B.; Galic, S.; Bruce, C.; Shields, B.J.; Skiba, B.; Ooms, L.M.; et al. Reactive oxygen species enhance insulin sensitivity. Cell Metab. 2009, 10, 260-272. [CrossRef]

150. Rebelos, E.; Rinne, J.O.; Nuutila, P.; Ekblad, L.L. Brain Glucose Metabolism in Health, Obesity, and Cognitive Decline-Does Insulin Have Anything to Do with It? A Narrative Review. J. Clin. Med. 2021, 10, 1532. [CrossRef]

151. Wang, D.; Pascual, J.M.; Yang, H.; Engelstad, K.; Mao, X.; Cheng, J.; Yoo, J.; Noebels, J.L.; De Vivo, D.C. A mouse model for Glut-1 haploinsufficiency. Hum. Mol. Genet. 2006, 15, 1169-1179. [CrossRef]

152. Ullner, P.M.; Di Nardo, A.; Goldman, J.E.; Schobel, S.; Yang, H.; Engelstad, K.; Wang, D.; Sahin, M.; De Vivo, D.C. Murine Glut-1 transporter haploinsufficiency: Postnatal deceleration of brain weight and reactive astrocytosis. Neurobiol. Dis. 2009, 36, 60-69. [CrossRef]

153. Hooijmans, C.R.; Graven, C.; Dederen, P.J.; Tanila, H.; van Groen, T.; Kiliaan, A.J. Amyloid beta deposition is related to decreased glucose transporter-1 levels and hippocampal atrophy in brains of aged APP/PS1 mice. Brain Res. 2007, 1181, 93-103. [CrossRef]

154. Pang, R.; Wang, X.; Pei, F.; Zhang, W.; Shen, J.; Gao, X.; Chang, C. Regular Exercise Enhances Cognitive Function and Intracephalic GLUT Expression in Alzheimer's Disease Model Mice. J. Alzheimers Dis. 2019, 72, 83-96. [CrossRef]

155. Pellerin, L.; Magistretti, P.J. Glutamate uptake into astrocytes stimulates aerobic glycolysis: A mechanism coupling neuronal activity to glucose utilization. Proc. Natl. Acad. Sci. USA 1994, 91, 10625-10629. [CrossRef] [PubMed] 
156. Bouzier-Sore, A.K.; Pellerin, L. Unraveling the complex metabolic nature of astrocytes. Front. Cell Neurosci. 2013, 7, 179. [CrossRef] [PubMed]

157. Magistretti, P.J.; Allaman, I. Lactate in the brain: From metabolic end-product to signalling molecule. Nat. Rev. Neurosci. 2018, 19, 235-249. [CrossRef] [PubMed]

158. Takahashi, S. Neuroprotective Function of High Glycolytic Activity in Astrocytes: Common Roles in Stroke and Neurodegenerative Diseases. Int. J. Mol. Sci. 2021, 22, 6568. [CrossRef]

159. Vlassenko, A.G.; Vaishnavi, S.N.; Couture, L.; Sacco, D.; Shannon, B.J.; Mach, R.H.; Morris, J.C.; Raichle, M.E.; Mintun, M.A. Spatial correlation between brain aerobic glycolysis and amyloid- $\beta$ (A $\beta$ ) deposition. Proc. Natl. Acad. Sci. USA 2010, 107, 17763-17767. [CrossRef]

160. Paul, R.; Borah, A. Global loss of acetylcholinesterase activity with mitochondrial complexes inhibition and inflammation in brain of hypercholesterolemic mice. Sci. Rep. 2017, 7, 17922. [CrossRef]

161. Duong, M.T.; Nasrallah, I.M.; Wolk, D.A.; Chang, C.C.Y.; Chang, T.Y. Cholesterol, Atherosclerosis, and APOE in Vascular Contributions to Cognitive Impairment and Dementia (VCID): Potential Mechanisms and Therapy. Front. Aging Neurosci. 2021, 13, 647990. [CrossRef] [PubMed]

162. Testa, G.; Staurenghi, E.; Giannelli, S.; Gargiulo, S.; Guglielmotto, M.; Tabaton, M.; Tamagno, E.; Gamba, P.; Leonarduzzi, G. A silver lining for 24-hydroxycholesterol in Alzheimer's disease: The involvement of the neuroprotective enzyme sirtuin 1. Redox Biol. 2018, 17, 423-431. [CrossRef]

163. Gamba, P.; Guglielmotto, M.; Testa, G.; Monteleone, D.; Zerbinati, C.; Gargiulo, S.; Biasi, F.; Iuliano, L.; Giaccone, G.; Mauro, A.; et al. Up-regulation of $\beta$-amyloidogenesis in neuron-like human cells by both 24 - and 27-hydroxycholesterol: Protective effect of N-acetyl-cysteine. Aging Cell 2014, 13, 561-572. [CrossRef] [PubMed]

164. Zhu, X.; Lee, H.G.; Perry, G.; Smith, M.A. Alzheimer disease, the two-hit hypothesis: An update. Biochim. Biophys. Acta 2007, 1772, 494-502. [CrossRef] [PubMed]

165. Bhatt, S.; Puli, L.; Patil, C.R. Role of reactive oxygen species in the progression of Alzheimer's disease. Drug Discov. Today 2021, 26, 794-803. [CrossRef] [PubMed] 